\title{
Global West, American Frontier
}

Author(s): David M. Wrobel

Source: Pacific Historical Review, Vol. 78, No. 1 (February 2009), pp. 1-26

Published by: University of California Press

Stable URL: http://www.jstor.org/stable/10.1525/phr.2009.78.1.1

Accessed: 21-06-2016 18:51 UTC

Your use of the JSTOR archive indicates your acceptance of the Terms \& Conditions of Use, available at

http://about.jstor.org/terms

JSTOR is a not-for-profit service that helps scholars, researchers, and students discover, use, and build upon a wide range of content in a trusted digital archive. We use information technology and tools to increase productivity and facilitate new forms of scholarship. For more information about JSTOR, please contact support@jstor.org.

University of California Press is collaborating with JSTOR to digitize, preserve and extend access to Pacific Historical Review 


\section{Global West, American Frontier}

\section{DAVID M. WROBEL}

The author is a member of the history department at the University of Nevada, Las Vegas. This was his presidential address at the annual meeting of the Pacific Coast Branch, American Historical Association, in Pasadena, California, August 9, 2008.

This article questions the common assumption that nineteenth-century audiences in America and around the world viewed the American western frontier as an exceptional place, like no other place on earth. Through examination of travel writings by Americans and Europeans who placed the West into a broader global context of developing regions and conquered colonies, we see that nineteenth-century audiences were commonly presented with a globally contextualized West. The article also seeks to broaden the emphasis in post-colonial scholarship on travel writers as agents of empire who commodified, exoticized, and objectified the colonized peoples and places they visited, by suggesting that travel writers were also often among the most virulent critics of empire and its consequences for the colonized.

Despite the great weight of representations of a mythic, exceptional, and quintessentially American frontier West in the nineteenth century, and the equally enormous weight of scholarship on the mythic West that has piled up in the century or so since 1900, it is important to remember that the trans-Mississippi West was commonly viewed in the nineteenth century as a global West, as one developing frontier, one colonial enterprise, among many around the globe. Twentieth- and twenty-first-century scholars have exhibited a tendency to throw around the term "mythic West" with such

This address is dedicated to my friend and colleague Willard Rollings, our Native American historian at the University of Nevada, Las Vegas, who died on July 30, 2008, and to two Past Presidents of the AHA-PCB, the late Wilbur Jacobs and the late Martin Ridge, great friends and mentors, both to me and to the organization.

My coverage of Friedrich Gerstäcker, Richard Francis Burton, and Isabella Bird draws on my previously published articles, "Exceptionalism and Globalism: Travel Writers and the Nineteenth-Century American West," Phi Alpha Theta Presidential Address, The Historian, 68 (2006), 430-460, reprinted in David Roediger, ed., The Best American History Essays, 2008 (New York, 2008), 75-99, and "The Global West: Gerstäcker, Burton, and Bird on the Nineteenth-Century Frontier," Montana: The Magazine of Western History, 58 (Spring 2008), 24-34. I am grateful to these publications and their editors for permission to utilize these materials.

Pacific Historical Review, Vol. 78, No. 1, pages 1-26. ISSN 0030-8684

(c) 2009 by the Regents of the University of California. All rights reserved.

Please direct all requests for permission to photocopy or reproduce article content through the University of California Press's Rights and Permissions website, at http://www.ucpressjournals. com/reprintinfo.asp DOI: phr.2009.78.1.1. 
great enthusiasm and abandon that we are left to wonder in astonishment at the intellectual limitations of nineteenth-century Americans, and their global observers, who presumably subscribed so readily, so unthinkingly, to that colorful vision of their West as a world apart, a place like no other place on earth. To offer just a single example, even the late Robert Athearn, a truly accomplished and thoughtful historian, demonstrated a tendency, when it came to the mythic West, to let his rhetorical proclivities overwhelm his usual good judgment. Writing in 1953 about nineteenth-century British travelers to the West, he proclaimed:

Without exception, these travelers were prepared for the worst. . . . Steeped in the traditions of [James Fenimore] Cooper and filled with the literary atrocities of [John Hanson] Beadle, they came West expecting to see the landscape awhirl with beautiful maidens pursued by shrieking savages, who were in turn pressed by buckskin-garbed frontiersmen brandishing a formidable collection of hardware. ${ }^{1}$

The early Cold War years saw a revival of the notion of American exceptionalism rooted in the nation's frontier heritage. ${ }^{2}$ In this cultural climate, it was quite common to assume not just the primacy, but even the absolute hegemony, of exceptionalist visions of America and its West in the previous century. On reflection, though, it seems clear that a more complex world view was present in the nineteenth century. In addition to the steady diet of exceptionalist rhetoric and imagery surrounding the American frontier that has provided so much food for academic thought, there was another cultural diet, often equally voluminous, of globally contextualized

1. The notion that travel writers contributed in a significant way to the body of western mythology that developed in the nineteenth century is certainly evident in Ray Allen Billington, Land of Savagery, Land of Promise: The European Image of the American Frontier (New York, 1991), as well as in Robert G. Athearn, Westward the Briton (New York, 1953), quotation on 7-8.

2. See, for example, Ray Allen Billington, Westward Expansion: A History of the American Frontier (New York, 1949) [his textbook], Henry Nash Smith, Virgin Land: The American West as Symbol and Myth (Cambridge, Mass., 1950), as well as two anthologies of nineteenth-century European travelers' descriptions of the United States: Allan Nevins, America Through British Eyes (New York, 1948), and Oscar Handlin, This Was America: True Accounts of People and Places, Manners and Customs, as Recorded by European Travelers to the Western Shore in the Eighteenth, Nineteenth, and Twentieth Centuries (Cambridge, Mass., 1949). For more on the manifestations of early Cold War American exceptionalism in a range of academic disciplines, including history, see John Patrick Diggins, The Rise and Fall of the American Left (New York, 1992), 187-200. 
discussions and representations of the American West. Moreover, the concurrent intake and digestion of the exceptional and the global, of these visions of both an American frontier and a global West, did not leave nineteenth-century Americans, or their observers, in a perpetual state of bipolar disorder, but, rather, gave them a good deal more to ponder than a century of scholarship on the "Old West" would suggest. It might be best to think of the American frontier and the global West of the nineteenth century as a current and a counter-current that probably coexisted not all too uncomfortably in the consciousness of those people who thought about such things, in much the same way that advancing and receding tides mark the same shoreline, leaving it looking different, literally from moment to moment. ${ }^{3}$

Here I use travel writing as a lens onto this broad countercurrent of thinking about the global West during the nineteenth century. Travel writing constituted a genre that, prior to the professionalization of American academic disciplines in the latter years of that century, offered people a vital window onto the world around them. Travel writers offered up their expertise as historians, geographers, demographers, anthropologists, authorities on the natural and built environments, and they displayed their talents as prose writers, all to a highly receptive and sizable reading public. Travel writing was voluminous, ubiquitous, profitable, and widely discussed. Publishers earned much of their income-and, more importantly, the reading public gained much of its knowledge about the world-from travel books. ${ }^{4}$

3. Frederick Jackson Turner, of course, used the metaphor of the frontier as "the outer edge of the wave"; see Turner, "The Significance of the Frontier in American History" (1893), in John Mack Faragher, ed., Re-Reading Frederick Jackson Turner: "The Significance of the Frontier in American History" and Other Essays (1994; New Haven, Conn., 1998), 31-60, 32.

4. Regarding the great volume of nineteenth-century travel accounts, Mary Suzanne Schriber has noted that 1,765 books of travel were published in the United States between 1830 and 1900; see Schriber, Writing Home: American Women Abroad, 1830-1920 (Charlottesville, Va., 1997), 2. Lynne Withey, Grand Tours and Cook's Tours: A History of Leisure Travel, 1750-1915 (New York, 1997), 234, states that at least 1,044 travel books about the Middle East were published in the nineteenth century. Max Berger, The British Traveller in America, 1836-1860 (New York, 1943), 14, notes that 230 accounts by British travelers to the United States were published between 1836 and 1860. For a good introduction to a wide range of the better-known nineteenth-century travelers' accounts of the West, see John Francis McDermott, ed., Travelers on the Western Frontier (Urbana, Ill., 1970); Billington, Land of Savagery, Land of Promise; and, most recently, Roger L. Nichols, "Western Attractions: Europeans and America," Pacific Historical Review, 74 (2005), 1-17. 
Some of these travel writers contributed to the powerful mythology that surrounded the region, but the writers focused on here envisioned a West that was very much in the world, not apart from it. In doing so, they offered an important counter-narrative to the exceptionalized visions of the West that were concurrently being constructed by a wide range of artists, writers, and showmen, as well as by actual western settlers who recorded their reminiscences, formed pioneer and old settler societies, and worked collectively to mold a story of the western past that rendered their own experiences laudable, memorable, and exceptional. ${ }^{5}$ Moreover, I suggest here, with respect to the American West (and perhaps more generally, too), that we would do well to move beyond the current parameters of post-colonial scholarship in our considerations of these travel writers. Since the publication of Edward Said's Orientalism (1978) and Marie Louise Pratt's Imperial Eyes (1992), the trend has been to view travel writers as agents of empire who exoticized, objectified, and commodified colonial "others," thereby facilitating the process by which empire was justified, supported, and consumed in the mother countries. ${ }^{6}$ There is, to be sure, a great deal of validity to this post-colonialist perception; many travel writers certainly can be considered agents of empire. However, I suggest here that, while the travel-writing genre certainly included among its practitioners those whose work aided the consumption of empire, it was more nuanced than post-colonial theory has generally allowed. Both architects of empire and forceful critics of imperialism, as well as those whose accounts were marked by a great deal of ambiguity about imperial projects, have been placed together

5. For more on these organized efforts to memorialize the frontier past, see David M. Wrobel, Promised Lands: Promotion, Memory, and the Creation of the American West (Lawrence, Kans., 2002), Clyde A. Milner II, "The Shared Memory of Montana Pioneers," Montana: The Magazine of Western History, 37 (Winter 1987), 2-13, and Milner, "The View from Wisdom: Region and Identity in the Minds of Four Westerners," in ibid., 41 (Summer 1991), 2-17.

6. Edward Said, Orientalism (New York, 1978); Said, Culture and Imperialism (New York, 1994); Mary Louise Pratt, Travel Writing and Transculturation (London, 1992). See also David Spurr, The Rhetoric of Empire: Colonial Discourse in Journalism, Travel Writing, and Imperial Administration (Durham, N.C., 1993), and Inderpal Grewal, Home and Harem: Nation, Gender, Empire, and the Cultures of Travel (Durham, N.C., 1996). Recent examples of the post-colonial approach to American western travel writings include Martin Padget, Indian Country: Travels in the American Southwest, 1840-1935 (Albuquerque, 2004), and Robert Campbell, In Darkest Alaska: Travel and Empire Along the Inside Passage (Philadelphia, 2007). Also useful regarding the relationship between travel and empire is Cecilia Morgan, 'A Happy Holiday': English Canadians and Transatlantic Tourism, 1870-1930 (Toronto, 2008). 
as if their voices and visions were harmonious. In short, travel writers could be agents of empire, but they could be forceful critics of empire, too. Whatever their particular predilections, their tendency was certainly to de-exceptionalize the American West, placing it squarely within the wide world of empire. A meeting of two renowned travelers at the mid-point of the century exemplifies this tendency.

\section{From Germany to California, and around the world}

In 1847 the American travel writer John Lloyd Stephens and the legendary German scientist and traveler Alexander von Humboldt met in Berlin. Stephens was the author of some of the bestselling travel books of the late 1830s and early 1840s about places from Arabia, to Southern and Eastern Europe, to Central America. ${ }^{7}$ He had become the vice-president and director of the Ocean Steam Navigating Company and traveled from New York to Bremen on the line's inaugural voyage. After arriving in Bremen, Stephens went on to Berlin, hoping to gain an audience with Humboldt. Humboldt granted him an hour, and Stephens expected that the time would be devoted to a discussion of the mysterious decline of the ancient Mayan civilization, about which both men had written extensively. But Humboldt had no interest in dwelling on the distant American past; instead, he wanted to discuss the tumultuous American present as evidenced in the ongoing war between the United States and Mexico. The imperial ambitions of the United States had clearly caught the attention of European observers. $^{8}$

Not surprisingly, in the wake of the war and the California Gold Rush, a flood of writings by European and American travelers to the newly acquired lands of the West appeared in print.

7. John Lloyd Stephens is the subject of an excellent chapter in Larzer Ziff, $R e$ turn Passages: Great American Travel Writing, 1790-1910 (New Haven, Conn., 2000), 58117 , from which my coverage is drawn. His works of travel include Stephens, Incidents of Travel in Egypt, Arabia Petraea, and the Holy Land (1837); Stephens, Incidents of Travel in Greece, Turkey, Russia, and Poland (1838); Stephens, Incidents of Travel in Central America, Chiapas, EO Yucatan (1841); and Stephens, Incidents of Travel in Yucatan (1843).

8. Larzer Ziff recounted this meeting in Ziff, Return Passages, 113-114. I am indebted to Andrew Cayton who drew my attention to the Stephens-Alexander von Humboldt encounter in his paper, Cayton, "The Imperial Republic: War and Expansion of an Empire of Liberty," in the session "United States Empire and Its Implications for History-Roundtable," at the annual meeting of the American Historical Association, Jan. 8, 2006, Philadelphia. 
Among them was a scathing critique of empire by another German, Friedrich Gerstäcker. Gerstäcker's Narrative of a Journey Round the World (1853) placed the American West into a broader global framework of gold rushes and their terrible costs for indigenous peoples. Gerstäcker, the author of approximately 150 books of travel, adventure stories, and novels, was an enormously popular figure in the second half of the nineteenth century. With a small government grant and a publisher's advance, he left home in 1849 with the ostensible purpose of examining the state of the German colonies in Brazil, Argentina, and Chile. After crossing the Atlantic to South America, Gerstäcker ended up traversing the Pampas and Cordilleras on horseback, then went to California in the midst of its gold rush, and on to the Hawaiian and Society Islands, Australia, New Zealand, and Java, before returning to Germany in 1852. His account was published in 1853 in Germany, England, and the United States. ${ }^{9}$ Little known today, Narrative of a Journey Round the World is one of the most remarkable travel books of the nineteenth century.

In the book, Gerstäcker emphasized the harrowing impact of white conquest on the indigenous peoples of California. He noted that, "while the natives of California [might] resemble the Eastern tribes in stature and complexion, they do not most assuredly in warlike character, for they are really the most harmless tribes on the American continent; let white people, who have driven them to desperation, say what they please against it." Gerstäcker added that the Indians had "no offensive arms at all, except bows and arrows, and these are small and powerless." 10 The consequence of these incongruencies between the California Indians and newly arrived white Americans, with respect to both martial inclination and capacity, was horrific. Gerstäcker charged that "the whites behaved

9. Friedrich Gerstäcker, Narrative of a Journey Round the World: Comprising a Winter Passage Across the Andes to Chile, with a Visit to the Gold Regions of California and Australia, the South Sea Islands, Java, $\mathcal{E}^{2} \mathrm{c}$ (New York, 1853), also published in an abridged British edition, Gerstäcker's Travels: Rio de Janeiro, Buenos Ayres, Ride through the Pampas, Winter Journey Across the Cordilleras, Chile, Valparaiso, California and the Gold Fields, trans. Friedrich Gerstäcker (London, 1854); the German edition was published in Stuttgart in 1853-1854. For more on Friedrich Gerstäcker's life and travels, see Jeffrey Sammons, "Friedrich Gerstäcker," in Siegfried Mews and James Hardin, eds., Nineteenth-Century German Writers, 1841-1900 [vol. 129 of Dictionary of Literary Biography] (Detroit, Mich., 1993), 110-119, and Sammons, Ideology, Mimesis, Fantasy: Charles Sealsfield, Friedrich Gerstäcker, Karl May, and Other German Novelists of America (Chapel Hill, N.C., 1998), 112-200.

10. Gerstäcker, Narrative of a Journey Round the World, 214. 
worse than cannibals toward the poor, inoffensive creatures, whom they had robbed of nearly every means of subsistence and now sought to trample underfoot." 11 His account of brutally violent acts committed with impunity by whites against Indians serves as a microcosm of the war of extermination that white settlers were waging against California Indians. California's indigenous population numbered around 150,000 in 1846; less than two decades later it was between 25,000 and 30,000. ${ }^{12}$

Gerstäcker left California in 1851 and traveled via the Hawaiian Islands to Australia, another place that had been turned upside down by the discovery of gold. ${ }^{13}$ Here, too, he commented upon the precipitous decline of the indigenous population and the role of white colonizers in the process. From Australia, he made one last stop on his global journey at the Dutch colony of Java. There he offered a stinging indictment of Dutch colonialism before providing a comparative analysis of European colonialisms in which the Dutch actually came off quite well:

the Hollander leaves the native in his home, and to his gods, and does not trouble his soul as well as his body. Their households and their household god $[s i c]$ are left to them; and they are not driven from the graves of their fathers by deeds and contracts, of which they understand nothing, and by persuasions and agreements closed with some chiefs, and enforced finally upon the whole nation, as English and Americans have done only too frequently. ${ }^{14}$

His account, with its comparisons of the Californian and Australian gold rushes, European and American colonial systems, and the catastrophic demographic declines of indigenous peoples on different continents, reminds us that such global contextualization of the American West was part of the public record. Moreover, as entire indigenous groups among the world's races appeared to be heading for extinction, Gerstäcker pulled no punches in citing the genocidal acts of white people as the primary cause. The U.S.

11. Ibid., 216.

12. See Benjamin Madley, "California's Yuki Indians: Defining Genocide in Native American History,” Western Historical Quarterly, 39 (2008), 303-332.

13. For a contemporary account of the Australian gold rush, see Edward Hammond Hargraves, Australia and its gold fields: a historical sketch of the progress of the Australian colonies, from the earliest times to the present day; with a particular account of the recent gold discoveries, and observations on the present aspect of the land question . . . (London, 1855).

14. Gerstäcker, Narrative of a Journey Round the World, 569-570. 
West was just one part of Gerstäcker's world, another developing frontier marked by violence against natives; it was not exceptional, not a world apart, but very much a West in the world. ${ }^{15}$ Moreover, Gerstäcker's account illustrates that not every European or European American traveler viewed the world through blinkered imperial eyes. Nevertheless, there certainly was a disturbingly dark side to travel writing that we need to consider, and where better to begin than with an early publication from an Englishman who would later become the founding father of eugenic pseudo-science.

\section{From "Darkest Africa" to the "Mormon Kingdom"}

Francis Galton's popular book The Art of Travel: or, Shifts and Contrivances Available in Wild Countries was first published in 1855 and in seven subsequent editions by 1893. A guidebook as well as a travel narrative, The Art of Travel has quite a history. The book's material was drawn in part from the author's own exploration of South West Africa in 1850-1852 (Galton was the first European to explore northern Namibia) for which the Royal Geographical Society awarded him its Founder's Medal in $1854 .^{16}$ In assembling the volume, Galton also made good use of the reports of various other explorers in the 1830s and 1840s, including Charles Sturt and F. W. Ludwig Leichhardt in Australia, John Palliser in the Canadian Rockies, and Col. John C. Frémont in what was soon to become the U.S. Far West. Galton also utilized the reports of Richard Francis Burton of his adventures in Mecca in 1852-1853, the American Commodore Matthew Perry's arrival in Japan in 1853, and the Abbé Huc's account of his journey from China to Lhasa, also published that year. In addition, he drew on his cousin Charles Darwin's The Voyage of the Beagle (1840) and, in preparing the fourth edition of The Art of Travel (1867), also had at his disposal Darwin's The Origin of Species (1859). ${ }^{17}$

15. Gerstäcker's coverage of Gold Rush California comprises one-fifth of the book, but illuminating parallels and departures between California and other places are made throughout. The book is divided into five parts: South America, California, the Hawaiian Islands, Australia, and Java.

16. For good coverage of Francis Galton's African travels, see Nicholas Wright Gillham, A Life of Sir Francis Galton: From African Exploration to the Birth of Eugenics (New York, 2001), 61-92.

17. Dorothy Middleton, "Introduction," in Sir Francis Galton, Francis Galton's The Art of Travel (1872), a reprint of The Art of Travel; or, Shifts and Contrivances Available in Wild Countries [fifth edition] (Harrisburg, Pa., 1971), 5-17, 5, 6-7, 12. 
In his preface to that fourth edition (1867), Galton complained that a reviewer of the previous edition (1860) had accused him of copying from Capt. Randolph B. Marcy's popular work The Prairie Traveller (1859), a similar kind of book-both travel narrative and guide to survival-about the western American frontier. Clearly irritated by the charge that a British writer would plagiarize from an American-authored book, Galton insisted that the passages in question were all taken from the second edition of his book, published in 1856, three years before Marcy's work. Galton proclaimed that he was the victim of intellectual theft, not the perpetrator. But for our purposes, the issue of who appropriated what from whom is of less significance than the fact that Galton had drawn on accounts from explorers across the globe, including those who traveled in the American West (even if Marcy's was not among them). Likewise, numerous accounts of western American travel utilized Galton's book. Furthermore, reviewers and general readers considered these works about different frontiers together. ${ }^{18}$

But what were the intellectual pearls of wisdom whose ownership Galton had made such a concerted point of defending in his 1867 preface to The Art of Travel? In addition to providing practical advice on how to pitch tents, pack food, and defend those encampments and supplies from hostile forces, Galton offered advice on the "Management of Savages." "A frank, joking, but determined manner," he insisted, "joined with an air of showing more confidence in the good faith of the natives than you really feel, is the best." Galton further advised that, "If a savage does mischief, look on him as you would on a kicking mule, or a wild animal, whose nature is to be unruly and vicious, and keep your temper quite unruffled." Then, if acute hostilities did arise and require retaliation, he further instructed, "recollect that it is not the slightest use to hit

18. The mid-nineteenth-century world of travel and travel writing was not comprised of the separate and disconnected experiences of sojourners on separated continents. Quite the contrary, the wide world of war, empire, trade, and travel brought continents together and into comparative context. Travelers to the American West could learn from the experiences of travelers to Africa and other "undeveloped frontiers," and vice versa. There was nothing novel in the mid-nineteenth century about these processes of mutual edification among and between European travelers to the world's various frontiers and its established and prospective colonies. It is worth remembering that the Scottish explorer Mungo Park's popular work Travels in the Interior of Africa, recounting his remarkable journey to the Niger River, had appeared a halfcentury earlier, in 1799. 
a negro on the head with a stick, as it is a fact that his skull endures a blow better than any part of his person." ${ }^{19}$ As for women, Galton explained that "if some of the natives take their wives [on expeditions] it gives great life to the party ... and a woman will endure a long journey nearly as well as a man and certainly better than a horse or bullock." ${ }^{20}$ For evidence of the physical endurance of Native women, Galton offered the observations of the eighteenthcentury British traveler Samuel Hearne who claimed that his famous third expedition through Britain's Northwest Territory to the Arctic Ocean (1770-1772) was a success largely because of the presence of Chipewyan Chief Matonabbee's six wives who did all of the heavy lifting and carrying. ${ }^{21}$

Galton also commented on the general untrustworthiness of "Natives," insisting that large numbers of them should never be permitted to enter one's camp at the same time, since their tendency was "to collect quietly in a friendly way, and at a signal to arise en masse and overpower their hosts." Moreover, Galton warned that natives "were not to be believed when they profess to have left their weapons behind," noting that Captain Sturt "had known Australian savages to trail their spears between their toes, as they lounged toward him through the grass, professedly unarmed." ${ }^{22}$ Clearly, for Galton, the indigenous inhabitants of different continents-Australia, the Americas, and Africa-were alike enough for his advice and Sturt's to be globally applicable.

Galton, of course, was a founder of the Social Darwinist movement and would go on to coin the term "eugenics" in 1883. Upon his death in 1911, he left funds to establish the Galton Laboratory of National Eugenics at University College London (later renamed, less offensively, the Galton Laboratory, Department of Human Genetics and Biometry). He has been positioned within Holocaust studies as one of the direct progenitors of racial anti-Semitism and thus of the exterminationist policies of the Third Reich. There may

19. Galton, The Art of Travel, 308, 312.

20. Galton, The Art of Travel [first edition] (1855), 58.

21. Ibid., 58-59.

22. Galton, The Art of Travel [eighth edition] (London, 1893), 313. Nicholas Wright Gillham has provided some good discussion of the book in Gillham, A Life of Sir Francis Galton, 98-101. For more on Galton's African travels, see Galton, The Narrative of an Explorer in Tropical South Africa (London, 153); Galton, Memories of My Life (New York, 1909); and Michael Bulmer, Francis Galton: Pioneer of Heredity and Biometry (Baltimore, 2003), 11-18. 
be no more infamous example of the sinister side of global travel writing than Sir Francis Galton. Moreover, Galton's experiences in South West Africa in the middle of the nineteenth century and his synthesis of writings by other white explorers about the far-flung regions and "savage peoples" of the globe surely helped shape his later theories of a world hierarchy of the human race. ${ }^{23}$ The Art of Travel reads not just like a practical guide to survival in "savagedom," but an enthusiastic invitation to vigorous Anglo Saxon adventurers to take up the strenuous life and do some hard traveling, dangerous exploring, and managing of savages. Scholars in search of unabashedly racist imperial visions constructed through travelers' eyes have in Galton an exemplar of that tradition. But that scholarly search is complicated by the experiences and writings of another famed British adventurer of the period.

The same year that The Art of Travel was first published (1855), the first of three of the most thrilling travel accounts of the century appeared, all the work of a single traveler, Richard Francis Burton. Burton's Personal Narrative of a Pilgrimage to El-Medinah and Meccah (3 vols., 1855-1856) recounted his 1852-1853 journey to Mecca disguised as an Arab and his entry into that hallowed site. ${ }^{24}$ First Footsteps in East Africa (1856) described Burton's dramatic exploits traveling in disguise as a Muslim merchant through Somalia to the "forbidden" city of Harrar in 1855. And, in The Lake Regions of Central Africa (1860), Burton recounted his "discovery" of Lake Tanganyika, Africa's second-largest lake.

His experiences on these journeys were memorable, to say the least. On the first of them, to El-Medinah and Mecca, Burton performed a self-circumcision to hide further his white Christian identity and facilitate his entry into those sacred sites. While in Harrar

23. Surprisingly, scholars of the eugenics movement have had relatively little to say about Galton the traveler/travel writer, although the connection between those early experiences and his later work in eugenics seems clear. Galton's closing comments in The Art of Travel, "On Concluding the Journey," are interesting in this regard. He reminded travelers to be sure to record their impressions very carefully at the end of the trip, even if those experiences seem absolutely unforgettable at the time. Warning those potential chroniclers, he noted that "the crowds of new impressions, during a few months or years of civilized life, will efface the sharpness of the old ones. I have conversed with men of low mental power, servants and others, the greater part of whose experience in savagedom has passed out of their memories like the events of a dream." Galton, The Art of Travel [fifth edition] (1872), 351.

24. Galton had in fact drawn on this work by Sir Richard Francis Burton in writing The Art of Travel. 
on his second trip, Burton's small party was attacked by hundreds of local warriors, and a javelin went through both his cheeks, "carrying away four teeth and transfixing the palate," as his wife Isabel later described it. Friends managed to extract the javelin and wired up his jaw, and he and the surviving members of his party returned to England. (Incidentally, as soon as his jaw had healed, Burton headed off to the Crimea, where a war was raging.) On the third of these expeditions, to the Central African lakes, Burton fell prey to numerous jungle diseases and nearly died. Isabel Burton, who had a flair for the dramatic and a deep commitment in her biography of her husband to the shaping of his legacy, wrote that he "had suffered twenty-one attacks of fever, had been partially paralyzed and partially blind; he was a mere skeleton, with brown yellow skin hanging in bags, his eyes protruding, and his lips drawn away from his teeth."25

Richard Burton spent a good portion of his life engaged in these remarkable adventures and in writing thrilling accounts of those exploits (thirty-nine volumes) for an eager public on both sides of the Atlantic Ocean. With knowledge of some twenty languages and an unparalleled understanding (among those in the western world) of the cultures of the Middle East and Africa, he was "the preeminent nineteenth-century British travel writer, a brilliant linguist and translator, a pioneer anthropologist, a poet, a civil engineer, a field cartographer, a soldier, one of Europe's best swordsmen, a diplomat, and a geologist." (He was also a talented amateur surgeon, which was rather fortunate for him!) But Burton is known to historians of the American West for his weighty (600-page) work The City of the Saints, and across the Rocky Mountains to California (1861), which resulted from a three-month visit to the United States in 1859, three weeks of which were spent in Salt Lake City. ${ }^{26}$ Because of his writings about other colonial frontiers,

25. Sir Richard Francis Burton, Personal Narrative of a Pilgrimage to El-Medinah and Meccah (3 vols., London, 1855-1856); Burton, First Footsteps in East Africa; or, An Exploration of Harrar (London, 1856); and Burton, The Lake Regions of Central Africa: A Picture of Exploration (2 vols., London, 1860). The descriptions of the books draw on John R. Pfeiffer's excellent overview of Burton's life and work, Pfeiffer, "Sir Richard Francis Burton," in Barbara Brothers and Julia Gergits, eds., British Travel Writers, 1837-1875 [vol. 166 of Dictionary of Literary Biography] (Detroit, Mich., 1996), 98-119, 105-106. Isabel Burton's description of her husband's health is quoted in Fawn M. Brodie, "Editor's Introduction," in [Sir Richard Francis Burton] Fawn M. Brodie, ed., The City of the Saints, and across the Rocky Mountains to California (New York, 1963), xvi-xvii.

26. Pfeiffer, "Sir Richard Francis Burton," 98-119, 100. 
Burton was already well known by people in the American West when he arrived. ${ }^{27}$

Burton's study of the Mormons, like all of his works of travel and adventure, was memorable, but it did not present the Mormon kingdom as a truly exceptional or even particularly unusual place. In fact, Burton's coverage of western American cultures and landscapes in The City of the Saints has to be viewed within the much broader context of his world travels. As a lieutenant in the British army in India, he had demonstrated a rare ability to cut away the veil of cultural stereotypes of Indians and thus understand their culture. Burton's reward for spending time with his Indian friends was to have the contemptuous label "white Nigger" bestowed on him by his fellow officers. ${ }^{28}$

In his assessments and descriptions of western American cultures and landscapes in The City of the Saints, he was similarly able to move beyond the pervasive stereotypes and view Mormonism on its own terms. He declared there was nothing immoral or unnatural about polygamy-he had visited other polygamous cultures in the course of his world travels, particularly in Africa and the Near East-and he exhibited a lack of prejudice that contrasted sharply with the prevailing viewpoint that emphasized the licentiousness and depravity of Mormons. ${ }^{29}$ Isabel Burton insisted, and hoped, that her husband had not practiced what he preached concerning the normality of non-monogamous relationships. (Incidentally, Burton had left England for the Mormon polygamous kingdom

27. Moreover, Randoph B. Marcy's The Prairie Traveller and Galton's The Art of Travel were well known to Burton. Two years after the publication of The City of the Saints, in 1863, as the Civil War raged, Marcy's famous guidebook The Prairie Traveller was republished, and Burton edited and annotated the volume; the two travelers had met during Burton's trip to Salt Lake City. Burton had actually drawn heavily on the earlier edition of The Prairie Traveller in writing The City of the Saints. Burton noted in his preface to Marcy's book that what he had to offer was not expertise of travel and adventure on the American frontier that could rival Marcy's, but, rather, "a little collateral knowledge gained in other lands." This "little collateral knowledge" amounted to a quite elaborate global comparative framework for describing non-white peoples and landscapes that emphasized similarities while at the same time recognizing significant cultural differences.

28. See Brodie, "Editor's Introduction," ix.

29. Fawn M. Brodie, "Sir Richard F. Burton: Exceptional Observer of the Mormon Scene," Utah Historical Quarterly, 38 (1970), 295-311. In her "Editor's Introduction" to The City of the Saints, Brodie noted that Burton "was trapped in the century least capable of appraising his talents, confined and penalized by the pruderies of Victorian England." Brodie, "Editor's Introduction," vii. 
before Isabel had consented to marry him and had written her a note instructing her to make up her mind during the three months that he would be gone. $)^{30}$

A month of those three was spent crossing the Great Plains. In his account of that journey, Burton drew comparisons of Native American and African totemism and of the indigenous cultures of the American West and those of the Tartars, Afghanis, and Mongolians in northern India. Burton's global positioning of the West was evident in his stated rationale for taking the trip: "I had long determined to add the last new name to the list of 'Holy Cities'; to visit the young rival [soi-disant] of Memphis [the ancient city of northern Egypt], Benares [in northern India], Jerusalem, Rome, Meccah." ${ }^{11}$ Thus, the Mormons' promised land was for Burton one more important religious site, best understood not in stark juxtaposition with the rest of the United States or the rest of the U.S. West, but in relation to other world capitals of religion.

Burton's descriptions of the Great Plains landscape were also presented within a global comparative framework: "Nothing, I may remark, is more monotonous, except the African and Indian jungle, than these prairie tracks," Burton wrote, adding, "As far as the eye could see the tintage was that of the Arabian desert." For a journey across the plains, Burton recommended that travelers carry a pistol (for protection against would-be robbers), a parasol (for protection against the sun), and a good supply of opium (for protection against the boredom of the journey). To his mind's eye, Scott's Bluff from a distance resembled the Arabian city of Brass, and Independence Rock seemed much like the Jiwe la Mkoa (the Round Rock) in eastern Unyamwezi. Indeed, the physiographic make up of the Utah Territory itself he compared to Central Equatorial Africa ["a trough elevated 4,000 to 5,000 feet above sea level, subtended on all sides by mountains 8,000 to 10,000 feet high, and subdivided by transverse ridges"]. He likened the region's climate to that of the "Tartar plains of High Asia," and the altitude sickness experienced at the territory's highest elevations to that experienced "upon Mont Blanc and even in Tibet." Vast stretches of Burton's West, along with its distinguishing landmarks and climatic

30. Ibid., xviii and xxxi. Brodie noted that, upon his return from the American West, Burton insisted that Isabel choose between him and her mother, or he would leave for India; three weeks later, in January 1861, they were married.

31. Brodie, ed., The City of the Saints, 3. 
characteristics, seemed very much like others he had experienced across the globe. ${ }^{32}$

The 100-page opening chapter of The City of the Saints is a tour de force of both global comparative landscape analysis and ethnographic analysis. The native peoples of the West were, in Burton's estimation, neither nature's most distinctive noblemen nor the converse of that romanticized image-that is, savages of unmatched cruelty and inhumanity. On the contrary, he paralleled the cultural practices of different American Indian groups with those of the whole range of peoples he had encountered on his global travels-Arab Bedouins, Hindustanis, African Somals-and drew further global cultural comparisons through reference to the works of other Anglo explorers such as David Livingstone. ${ }^{33}$ However, Burton's expansive comparative framework was often none too flattering to the victims of Anglo American empire and quite laudatory when it came to the practices of the colonizing powers. For example, Burton paralleled the U.S. government's treatment of Native Americans with Great Britain's treatment of East Indians, praising both empires for their paternalism and for treating their respective indigenous subjects "as though they were a civilized people." 34

Burton's estimation of the comparative lack of civilization in indigenous America was itself complicated by his own understanding of cultural differences among and between different Native American cultures. At one point in The City of the Saints, Burton referred to all North American Indians as "savages"; yet, in the

32. Sir Richard F. Burton, Wanderings in Three Continents (London, 1901), 153, 155. Brodie highlighted these comparisons in her introduction to Burton's The City of the Saints, xix-xx. The 100-page-long opening chapter of the book is best described as a comparative analysis of the landscapes and peoples of the American West, the Indian subcontinent, Africa, and the Middle East. For the Scott's Bluff-Brass comparison, see Brodie, ed., The City of the Saints, 87; for the Independence Rock-Jiwe la Mkoa comparison, see ibid., 164; for the Utah Territory-Central Equatorial Africa comparison, see ibid., 302; for the global comparisons of climate and elevation, ibid., 304-305. For an early example of the drawing of comparisons between the landscapes and cultures of the American West and those across the globe, see Harriet Martineau's comparison of Nubia and the Nubians with the Mississippi and the "Indian grounds of Wisconsin," in Martineau, Eastern Life, Past and Present (3 vols., London, 1848), 1: 101-104, cited in Withey, Grand Tours and Cook's Tours, 244.

33. Burton compared Native American animal worship to that of the Kafir Backwana, as described in David Livingstone, Missionary Travels and Researches in South Africa (London, 1857), see Brodie, ed., The City of the Saints, 119.

34. Ibid., 37. 
very same paragraph, he pointed to the failure of the 1853 reservation system to take fully into account the different cultural backgrounds from which various Indian groups sprang, and he listed by name thirty separate Indian peoples. ${ }^{35}$ But ultimately, and in spite of any paternalistic instincts on the part of the federal government to assimilate Indians, he concluded that "the westward gravitation of the white race" was destined to push the "few survivors . . . into the inhospitable regions north of the 49th parallel, or into the anarchical countries south of the 32nd."36 Much like George Catlin, Burton saw little hope for North American Indians within the contours of the U.S. western empire. ${ }^{37}$

Unlike Catlin, though, Burton went so far as to offer his American cousins some advice to facilitate the subjugation of indigenous opposition to their nation's westward expansion, advice based on his own personal experiences in Africa and India. Alexis de Tocqueville (whose Democracy in America [1835, 1840] was rediscovered in the early Cold War years as one of the foundational texts of that new era of American exceptionalism) had suggested, in his "First ..." and "Second Reports on Algeria" (1847), that the French needed to learn from the example of the U.S. subordination of Indian peoples and apply that lesson of colonial conquest and management of empire to their own possessions in Algeria, which were then in an acute state of unrest. ${ }^{38}$ Burton, in The City of the Saints, contended that the United States and Britain, in their respective western and eastern empires, could now learn from the military example of the French in Algeria. He explained that the system of outposts maintained by the United States in the transMississippi West and by the British in India was unworkable and that a more centralized system was required that would allow for

35. Ibid., 38 .

36. Ibid., 41.

37. George Catlin's Adventures of the Iowa and Ojjibeway Indians in England, France, and Belgium $(1852,1848)$, structured as a travelogue through Indian eyes, emphasized, in quite damning language, the role of the United States government in effecting Indian population decline.

38. See Jennifer Pitts, "Introduction," in Alexis de Tocqueville, Writings on Empire and Slavery, trans. and ed. Jennifer Pitts (Baltimore, 2001), ix-xxxxviii, especially xxi. The pertinent Tocqueville writings in the volume are: "Essays on Algeria" (October 1841), 59-116, "First Report on Algeria" (1847), 129-173, and "Second Report on Algeria" (1847), 174-198. 
the concentration of troops and weapons at the key sites of military action, "making them pivots for expeditionary columns ... that could be dispatched to wherever an attack or an insurrectionary movement required crushing." ${ }^{9}$

It might seem that a clearer case of the travel writer as a direct advocate or even agent of empire would be hard to find. Yet, Burton's emphasis on the cultural diversity of indigenous America and his constant parallels between the spiritual lives of American Indian groups and those of indigenous peoples across the globe hardly constituted a firm intellectual foundation for those who advocated a genocidal approach to the Indian problem and who would have their way at Sand Creek, Colorado, only a few years later (1864) and at points during the Indian Wars that followed the conclusion of the Civil War. While hardly a paragon of intercultural sensitivity, Burton's knowledge and understanding of other cultures far exceeded that of Galton and other like-minded travelers whose cultural blinkers ensured that they would see only savagery around every distant corner of the globe. ${ }^{40}$

\section{From the Western Rockies to the Near and Far East}

Gerstäcker, Burton, and Galton viewed the American West globally, but that perspective was by no means limited to men. The remarkable experiences of another intrepid Britisher, Isabella Lucy Bird, can also help us think about the significance of the global West of the nineteenth century and more particularly about how experiences in the West could provide a frame for experiences all around the world. Bird's A Lady's Life in the Rocky Mountains, a fascinating chronicle of her 1873 travels around Colorado, was published in London and New York in 1879; it was in its seventh edition by 1882 and has remained in print to this day. ${ }^{41}$

39. Brodie, ed., City of the Saints, 49-50.

40. Brodie pointed out (in ibid., xxxii) that "Burton disliked African natives generally, openly preferring Arabs or those of mixed blood in northern Africa. Said, in a probing analysis of Burton, in Orientalism, insisted that, for all his cultural knowledge and empathy, Burton was, in the last analysis, "an imperialist." Said pointed to Burton's "sense of assertion and domination over all complexities of Oriental life" and further noted that "the voice of the highly idiosyncratic master of Oriental knowledge informs, feeds into the voice of European ambition for rule over the Orient," see Said, Orientalism, 195-198, quotations on 195 and 196.

41. In 1856, the same year that Burton's account of adventures in East Africa appeared, Isabella Lucy Bird published her first travel book, a rather tame and forgettable 
Born in 1831, Isabella Bird was described by an acquaintance as "bucktoothed, stout, sickly, and short (four feet, eleven inches tall)." Earlier in her life, Bird's doctors "determined that her head was too large for her frame and advised her to avoid holding it up. ... Her family thought of her as an invalid, apt to die young., ${ }^{, 2}$ Yet Bird's description in A Lady's Life of her ascent of the 14,700foot Long's Peak in October 1873, with the assistance of that archetypal western desperado, one-eyed "Mountain Jim," and her winter horseback rides across the Colorado Plains and Rockies suggest a conquering of physical frailty that rivals the more familiar story of Theodore Roosevelt's transformation into muscular manhood. While climbing Long's Peak, Bird found a pair of overshoes, which, she wrote, were "probably left by the Hayden exploring expedition" a few years prior, and this may well have been the case, since few other white people had ascended the mountain by that early date. ${ }^{43}$

On her Colorado trip, Bird came to the Rockies by way of the Hawaiian Islands and then eastward from San Francisco. A Lady's Life is sprinkled with comparisons between the Rockies and the landscapes of Hawai $i$, and she compared her experiences herding cattle in Estes Park with her time as a vachero [sic] in Hawai'i. In Perry Park, near Castle Rock, while riding with the daughter of John Perry, Bird remarked upon that young woman's "vivacious descriptions of Egypt, Palestine, Asia Minor, Turkey, Russia, and other countries" in which she had traveled. One wonders if those descriptions inspired Bird or if the catalyst for global adventuring had come earlier. Whatever the case, Bird herself became a famous world traveler who climbed mountains, rode across deserts, and wrote book-length accounts (nine all together) of her adventures in Japan (1880 and 1898), Malaysia (1883), Persia and Kurdistan (1891), Tibet (1894), Korea (1897), and China (1899 and 1900), as well as the Hawaiian Islands (1875) and the American West. ${ }^{44}$

record of a trip to Canada and the United States that she undertook for the purpose of improving her health. Fortunately for lovers of good travel writing, Bird would return to the West a decade and a half later. For more on Bird, see Julia M. Gergits, "Isabella Lucy Bird," in Brothers and Gergits, eds., British Travel Writers, 1837-1875, 29-49, 32, 30. Isabella Bird, A Lady's Life in the Rocky Mountains (1879; Sausalito, Calif., 1977).

42. Gergits, "Isabella Lucy Bird," 32, 30.

43. Bird, A Lady's Life, 86.

44. Ibid., 135-36; Gergits, "Isabella Lucy Bird," 29-30. For more on Bird's Hawaiian travels, see Isabella Bird, The Hawaiian Archipelago: Six Months among the Palm Groves, Coral Reefs, and Volcanoes of the Sandwich Islands (London, 1875; New York, 1882). 
Scholars of the West have had little to say about Bird's global travels, which is unfortunate since some of the same issues that occupied her attention while in the Western Rockies are evident in her later accounts of travel in the Near and Far East. While Burton's descriptions of western landscapes and cultures were very much shaped by his global experience, Bird's global experience was shaped in no small part by her time in the West. Five years after she left the Rockies, Bird was in Japan and upon arrival was driven almost immediately by an impulse to get away from the major cities and treaty ports to which most foreign visitors restricted their travels and explore the "unbeaten tracks" and "savage wilds" of the region. ${ }^{45}$ In her aptly titled account of the trip, Unbeaten Tracks in Japan (1880), she discussed her journey to the island of Hokkaido to spend time with the Ainu people, the original inhabitants of the Japanese archipelago; she offered an assessment of them that paralleled her comments on California's Digger Indians in A Lady's Life, even if it was a shade more positive. She had described the latter as "perfect savages, without any aptitude for even aboriginal civilization ... altogether the most degraded of the ill-fated tribes which are dying out before the white races." She assessed the "savage life" of the Ainu as one "not much raised above the necessities of animal existence, timid, monotonous, barren of good, dark, dull...though at its lowest and worst considerably higher than that of many other aboriginal races." ${ }^{46}$

A few years after the publication of A Lady's Life, Bird was traveling across the Malay Peninsula, where no European steamers landed, a place generally believed to be "a vast and malarious equatorial jungle." In the resulting 1883 book, The Golden Chersonese (1883), Bird commented on indigenous population decline on the Malay Peninsula, writing, rather dismissively, "If they were swept away to morrow not a trace of them except their metal work would be ... found. Civilized as they are they don't leave any more impress on the country than a Red Indian would." Markedly less sensitive about the matter than some travel writers, she nonetheless

45. For more on this tendency among travelers to Japan of this era to stay on the beaten path, see Hugh Cortazzi, Victorians in Japan: In and Around the Treaty Ports (London, 1987).

46. Bird, A Lady's Life, 4; Isabella Bird, Unbeaten Tracks in Japan (Boston, 1987; originally published London, 1880), quotation from reprint, 259. 
exhibited the same tendency to place the demographic collapse of American Indians into a global context. ${ }^{47}$

In 1891 Bird rode across Persia and Kurdistan. ${ }^{48}$ In her late sixties, she undertook another horseback trip on a black stallion, from Tangier 1,000 miles across Morocco to the Atlas Mountains. She fell ill after returning to England and died in 1904, just short of her seventy-third birthday. Her adventurous life of travel and her voluminous printed accounts of those journeys, read by Europeans and Americans in the late nineteenth century and still read today, serve as a good example of how western American experiences could shape the experience of world travel, just as global travels could shape perceptions of the West. While Burton placed the world in the West, Bird placed the West in the world.

\section{"Across the Plains" and "Around the World"}

Gerstäcker, Galton, Burton, and Bird are just a few of the hundreds of nineteenth-century global travelers who viewed the American West within that larger world context. In placing the drama of the West on a global stage, these travel writers reminded Americans that they were thoroughly connected to the world of empire building and that their western frontier served as the primary stage for imperial endeavors, not an escape from them. After 1869 it would have been difficult, even for less intrepid travelers, not to see the western frontier in relation to that wider world. The completion of the American transcontinental railroad in that year closed the final link in a global transportation chain. Three years later Jules Verne's novel Around the World in Eighty Days (written in the travelogue form so popular at the time) appeared. In the book, the chief protagonist, Phileas Fogg, travels to Bombay, Calcutta, Hong Kong, Yokohama, and Shanghai, and then on to San Francisco, across the United States-with a three-hour delay on the Central Pacific Railroad in the Humboldt Ranges of Northeastern Nevada,

47. Like A Lady's Life and Unbeaten Tracks in Japan, this book was composed initially as a series of letters to her sister Henrietta in England. Isabella L. Bird, The Golden Chersonese and the Way Thither (London, 1883), 338-339. Karen M. Morin does provide some global contextualization for understanding A Lady's Life in Morin, "Narrating Imperial Adventure: Isabella Bird's Travels in the Nineteenth-Century American West," in Gary J. Hausladen, ed., Western Places, American Myths: How We Think About the West (Reno, Nev., 2003), 204-222.

48. By this time Bird had married and taken her husband's name, Bishop. 
courtesy of a lumbering herd of bison, and a thrilling ride on a sail-powered sled from Fort Kearney to Omaha, Nebraska-on to New York, across the Atlantic to Liverpool, and down to London, arriving just in time to win his bet that he could make the trip in eighty days. Also in 1872, British tour operator Thomas Cook, the father of modern mass tourism, led his first personally conducted 222-day world tour. In 1889 the American journalist/travel writer Nellie Bly completed a much-publicized trip around the world in just seventy-two days, following the Fogg/Cook route, which became the standard for world travelers. Indeed, Cook's itinerary created a travel infrastructure that in turn helped create a mountain of travel books for the late nineteenth-century public. ${ }^{49}$

That public would also have been exposed to the work of another British traveler, Robert Louis Stevenson, whose literary fame today stems largely from his novels Treasure Island (1883) and Kidnapped (1886). But Stevenson, like so many of the notable novelists and short story writers of his day, was a renowned travel writer, too. For romantic reasons, he traveled from Scotland to California in 1879, taking a train across the United States. An abridged account of the trip, "Across the Plains," was published in Longman's Magazine in 1883 and the full version finally appeared in book form in England in 1892. (The delay in publication can be explained in part by his publisher's and family's nervousness over the gritty realism of the account.) In that year, 1892, Congress renewed the Chinese Exclusion Act, and, while Stevenson's work clearly did not sway the political debate in any way, it may well have given American readers some food for thought in the years that followed. In a section of the account titled "Despised Races," Stevenson declared: "Of all the stupid ill-feelings, the sentiment of my fellow-Caucasians towards our companions in the Chinese car was the most stupid

49. The material on Thomas Cook, Jules Verne, and Nellie Bly is drawn from Withey, Grand Tours and Cook's Tours, 264-272. Included among the many late nineteenthcentury works of world travel by British writers are John Boddam-Whetham, Western Wanderings (1874); Mrs. F. D. Bridges, Journal of a Lady's Travels around the World (1883); John Francis Campbell, My Circular Notes (1876); Sir Charles Wentworth Dilke, Greater Britain: A Record of Travel in English-Speaking Countries during 1866 and 1867 (2 vols., 1868); Sir Richard Tangye, Reminiscences of Travel in Australia, America, and Egypt (1883); Mrs. Howard Vincent (Ethel Gwendoline), Forty Thousand Miles over Land and Water: The Journal of a Tour through the British Empire and America (2 vols., 1885); Sir Henry Morton Stanley, My Early Travels and Adventures in America and Asia (2 vols., 1895); and George Henry Peters, Impressions of a Journey around the World, including India, Burmah, and Japan (1897). 
and the worst." Stevenson proceeded to undermine popular stereotypes about the Chinese (their lack of cleanliness, etc.) and highlighted "the gulf between America's rhetoric of freedom and the failure of Americans to match that rhetoric in their actions." $\mathrm{He}$ then moved on to a discussion of the actions of his fellow passengers toward Native Americans, noting that the former displayed "a truly Cockney baseness" that made him "ashamed for the thing we call civilization." And, he added, in language that certainly seems applicable to contemporary debates over how best to address the legacies of racial injustice, "We should carry upon our consciences so much, at least, of our forefathers' misconduct as we continue to profit by ourselves." 50

Some readers of Stevenson's account might conclude that the work is just one of many by British travelers that exhibit the scolding, "holier-than-thou" attitude of representatives of that empire nation toward another, rival empire nation (and former colony) an "our colonialism is more benign and beneficent than yours" outlook. But whatever Stevenson's motivation, Anglo Americans (after 1895, at least, when the account was published in book form in America as The Amateur Emigrant) were exposed to his criticism of their racial attitudes and their nation's racial policies. This interesting and often accusatory dialogue between colonizing nations has not, to date, been the subject of post-colonial theory, yet it seems to constitute an interesting variant of Homi Bhabha's notion of hybridity. ${ }^{51}$ In criticizing another aspiring empire nation, British travel writers (and readers) may have become increasingly aware of the shortcomings of their own colonial systems, while American readers (of the very same texts) became more cognizant of the embarrassing incongruence between racial attitudes and democratic aspirations in their own country.

Another beneficiary of the wide world of travel engineered by Thomas Cook and an eventual critic of American empire was

50. Robert Louis Stevenson, Across the Plains: With Other Memories and Essays (London, 1892), 62, 64, 67. The work was later published as part of the full account of Robert Louis Stevenson's trip from Scotland to California, in Stevenson, The Amateur Emigrant: From the Clyde to Sandy Hook (Chicago, 1895; New York, 1899). For an excellent discussion of this work, see Gordon Hirsch, "Robert Louis Stevenson," in Barbara Brothers and Julia Gergits, eds., British Travel Writers, 1876-1909 [vol. 174 of Dictionary of Literary Biography] (Detroit, Mich., 1997), 268-288, 276-279.

51. Homi K. Bhabha, The Location of Culture (London, 1994). 
America's greatest writer of the nineteenth century, Mark Twain. "For the readers of the late nineteenth century," Twain scholar Jeffrey Melton reminds us, "Samuel Clemens was first and foremost a travel writer, not a novelist." ${ }^{52}$ Twain is best known to American audiences today for his novels, particularly The Adventures of Huckleberry Finn (1884) and The Adventures of Tom Sawyer (1876), but also for his American travel books Roughing It (1872) and Life on the Mississippi (1883). Twain's best-selling work during his lifetime was actually his second book and first overseas travel narrative, The Innocents Abroad (1869), which chronicled a five-month trip to Europe, the Near East, and the Holy Land. The book lampooned the enormously popular mid-century customs-and-manners school of travel writing, selling over 70,000 copies in its first year (and 125,000 in the first decade) ${ }^{53}$ It was sold by subscription; traveling salesmen and women peddled the book. ${ }^{54}$ A decade later Twain set sail for Europe to revive his flagging financial fortunes by writing a second European travel book, A Tramp Abroad (1880), a sequel of sorts to The Innocents Abroad, which sold 62,000 copies (by subscription) in its first year. A Tramp Abroad is the quintessential example of Twain the irreverent iconoclast, unimpressed with Europe's great cultural treasures and renowned landscapes. In his hilarious prefatory remarks, Twain spoofs the entire travel/adventure writing genre when he explains that he sent his agent off to examine the most significant sites ("the Furka Pass, the Rhone Glacier, the Finsteraarhorn and the Wetterhorn, etc.") and report back, thus saving himself the trouble of actual travel. A Tramp Abroad is an anti-travel narrative of sorts, yet it is perhaps the funniest travel book ever written. ${ }^{55}$

In 1895, after various failed financial ventures left him bankrupt, Twain decided to undertake a world lecture tour and write a world travelogue, Following the Equator (1897; sold by subscription in America and republished later that year as More Tramps

52. See Jeffrey Alan Melton, "Samuel Langhorne Clemens (Mark Twain), 18351910," in Donald Ross and James J. Schramer, eds., American Travel Writers, 1850-1915 [vol. 189 of Dictionary of Literary Biography] (Detroit, Mich., 1998), 65-78, 67, 68, and Sarah Bird Wright, "Harriett Beecher Stowe (1811-1896)," in ibid., 305-320, 307.

53. Melton, "Samuel Langhorne Clemens," 65-78, 68.

54. Subscription publishing was enormously popular at the time, and several more of Mark Twain's books were sold in this way.

55. Mark Twain, A Tramp Abroad (2 vols., New York, 1879), 2: 1. 
Abroad). ${ }^{56}$ The trip, which began in July 1895 and took Twain and his family to a hundred cities, proved to be a terribly tragic one; as he reached the end of his journey, in London (where he wrote the book), he learned in August 1896 that his favorite daughter, Susy, had died from meningitis at the age of twenty-four. Following the Equator has a harsh tone, far removed from the playful comedy of his earlier travel books.

During the course of the thirteen-month journey, Twain lectured to every British-speaking audience he could find-the bulk of his trip fell within the broad geographic contours of the British Empire. But the resulting book was no glorification of British imperialism. Quite the contrary, he commented on the consequences of colonization for people around the world, and, in doing so, he questioned the very concept of imperialism, just as Gerstäcker had a half-century earlier. Twain let loose his incomparable skepticism in writing about the natives of the Fiji Islands: "Only sixty years ago they were sunk in darkness; now they have the bicycle. ${ }^{57}$ In Australia he commented on indigenous population decline: "The white man knew ways of reducing a native population 80 per cent in twenty years." ${ }^{58}$ Twain then remarked on the absence of Australian aborigines from that country's museums and on the application of the word "native" "to Australian-born whites only"- the aborigines were referred to as "blackfellows." Then it struck Twain (whose treatment of Native Americans in Roughing It is thoroughly lamentable) that American Indians had suffered the same fate of erasure from U.S. museums. ${ }^{59}$

56. Twain's most recent biographer, Ron Powers, has little positive to say about Following the Equator, but Larzer Ziff, in an excellent treatment of Twain's travel writing in Return Passages, sees the enormous, even transformative, significance of the work. See Ron Powers, Mark Twain: A Life (New York, 2005), 582-584; Larzer Ziff, "Mark Twain," in Ziff, Return Passages, 170-221. Robert Cooper retraced Twain's global journey in his own travelogue; Cooper, Around the World with Mark Twain (New York, 2000). Unlike most of the other travelers treated here, Twain went on his journey around the world for no reason other than to make money, yet the end product is a travel book of enduring value.

57. Mark Twain, More Tramps Abroad (London, 1897), 54.

58. Ibid., 134-135. This coverage of Aboriginal population decline in Australia comes from the American version, Mark Twain, Following the Equator: A Journey Around the World (Hartford, Conn., 1898), 208-209.

59. Twain, Following the Equator, 155, quoted in Ziff, Return Passages, 215. Twain wrote: "In the great museums [of Australia], you will find all the other curiosities, but in the curio of chiefest interest to the stranger all of them are lacking. We have at home an abundance of museums, and not an American Indian in them. It is clearly an absurdity, but it never struck me before." 
Twain devoted a chapter to the savage campaign of extermination against the natives of Tasmania (Van Dieman's Land) ${ }^{60}$ Of the brutal regime in South Africa, he wrote: "There are many humorous things in the world; among them, the white man's notion that he is less savage than other savages.." ${ }^{\prime 1}$ As literary scholar Larzer Ziff has emphasized, the horrors of colonization and the brutal imposition of racial hierarchies that accompanied it reminded Twain of the terrible mistreatment of slaves in the Old Southwest during his Missouri boyhood. After watching a German hotel proprietor strike an Indian employee in Bombay, Twain experienced the painful memory of his father hitting "our harmless slave boy" and recalled witnessing another slave being killed by a white man. Twain's whole life came to make more sense as a result of his last global journey. ${ }^{62}$ It was not just his personal past but the American present, too, that was enlightened by Twain's travels. The experience of his last global journey made him critical of America's thrust toward empire in the wake of the Spanish-American War of 1898, and he became an important anti-imperialist voice. ${ }^{63}$

Twain reminded Americans in Following the Equator of the consequences of empire for the colonized, the conquered. He surely hoped that his American readers would learn from this global context. It was a long journey from the Far West of Roughing It, the creation of a brilliant young cynic, to the sage and tragic observations of a global traveler a quarter-century later. Like the journeys of Gerstäcker, Galton, Burton, Bird, and Stevenson, Twain's last travelogue deserves another look. ${ }^{64}$ It reminds us of the great power travel writers have to take us along vicariously, the better to understand ourselves globally. We could learn a great deal by putting the West back into that world.

60. Twain, Following the Equator, chapter 27, pp. 256-267.

61. Twain, More Tramps Abroad, 138.

62. Twain, Following the Equator, 352, quoted in Ziff, Return Passages, 218.

63. America's quest for empire had been justified in part by spokesmen who argued that the nation had lost its contiguous western frontier and needed new overseas frontiers if it were to retain its vigorous spirit. American imperialists were literally putting the West into the world in support of empire.

64. In a letter to his London publisher, Chatto and Windus, dated March 26, 1897, Twain wrote of More Tramps Abroad (the British title), which he had been busily revising: "I am more than satisfied with it these latter days. I wouldn't trade it for any book I have ever written-\& I am not an easy person to please." See Za Clemens, Samuel Langhorne, Manuscripts, 1-4, "Following the Equator," folder 1, Beinecke Library, Yale University, New Haven, Conn. 
To imagine that Americans in the nineteenth century were so smitten with the mythic West that they collectively and unreservedly viewed western America as exceptional, incomparable, and unparalleled is to ignore the mass of popular travel accounts that suggested the opposite. Similarly, to view travel writing as one great imperial archive and all its practitioners as mere imperial scribes is to render the genre more monolithic and less discerning than was actually the case. Some of the most insightful and popular travel writings of that century are best considered as a counter-narrative to American imperialism and to nationalistic, frontier-centered notions of American exceptionalism. ${ }^{65}$

The accounts of these travel writers, who saw in the American frontier a global West, remind us that, when we as scholars of earlier ages place the regions of our respective expertise into global comparative context, we are not necessarily doing something that the residents of those times and places could not do; we are not always providing them with parallels they could not have conceived of or seeing the world more clearly for them than they could have seen it for themselves. ${ }^{66}$ Quite the contrary; in the case of nineteenth-century Americans, we are continuing their work of seeing themselves, and thus seeing ourselves, within the larger world. That is an enterprise that seems particularly useful in this challenging moment in the American present, when wars, genocides, economic distress, and environmental challenges are forcing us all to think more deeply and critically about America's place in the world, and the world's place in America.

65. Interestingly, it was the very feeling that the far-flung recesses of the earth were now closer than ever because of steamships and railroads that actually nurtured the notion of a distinctive American frontier. The frontier concept served as an antidote of sorts to "globalization," to use a more contemporary term. The growing emphasis in the second half of the nineteenth century on the exceptional nature of that western frontier experience-the creation of a mythic West-provided a kind of nationalist escape from an emerging global reality in which the ostensibly immense geography of the United States was in actuality just a single stage of an integrated journey around the world, one page in a Thomas Cook book of tickets. Meanwhile, visitors from across the globe traveled more easily across the United States in the transcontinental railroad age, sometimes reminding Americans, as Stevenson did, of the multicultural reality of their nation and the common failure of their democratic rhetoric to match that reality.

66. John Gaddis, in his excellent essay "The Landscapes of History," in John Lewis Gaddis, The Landscapes of History: How Historians Map the Past (New York, 2002), emphasizes the role that historians play in constructing rich landscapes with the benefit of an enhanced angle of vision that develops as time passes and that contemporary observers of a particular event could not have enjoyed. While Gaddis is essentially correct, it is worth noting that historians do often exhibit a tendency to imagine the contours of the past as somehow simpler than those of the present. 